\title{
Article \\ Evaluation of Floxuridine Oligonucleotide Conjugates Carrying Potential Enhancers of Cellular Uptake
}

\author{
Anna Aviñó ${ }^{1,2, *}$, Anna Clua ${ }^{1,2}\left(\mathbb{D}\right.$, Maria José Bleda ${ }^{1}\left(\mathbb{C}\right.$, Ramon Eritja $^{1,2, *}$ and Carme Fàbrega ${ }^{1,2}(\mathbb{C}$ \\ 1 Institute for Advanced Chemistry of Catalonia (IQAC-CSIC), Jordi Girona 18-26, E-08034 Barcelona, Spain; \\ anna.clua@iqac.csic.es (A.C.); mjbqbi@cid.csic.es (M.J.B.); carme.fabrega@iqac.csic.es (C.F.) \\ 2 Networking Center on Bioengineering, Biomaterials and Nanomedicine (CIBER-BBN), Jordi Girona 18-26, \\ E-08034 Barcelona, Spain \\ * Correspondence: aaagma@cid.csic.es (A.A.); recgma@cid.csic.es (R.E.); Tel.: +34-934-006-100 (A.A.)
}

Citation: Aviñó, A.; Clua, A.; Bleda, M.J.; Eritja, R.; Fàbrega, C. Evaluation of Floxuridine Oligonucleotide Conjugates Carrying Potential Enhancers of Cellular Uptake. Int. J. Mol. Sci. 2021, 22, 5678. https:// doi.org/10.3390/ijms22115678

Academic Editor: Edmond Dik Lung Ma

Received: 31 March 2021

Accepted: 25 May 2021

Published: 26 May 2021

Publisher's Note: MDPI stays neutral with regard to jurisdictional claims in published maps and institutional affiliations.

Copyright: (c) 2021 by the authors. Licensee MDPI, Basel, Switzerland. This article is an open access article distributed under the terms and conditions of the Creative Commons Attribution (CC BY) license (https:// creativecommons.org/licenses/by/ $4.0 /)$.

\begin{abstract}
Conjugation of small molecules such as lipids or receptor ligands to anti-cancer drugs has been used to improve their pharmacological properties. In this work, we studied the biological effects of several small-molecule enhancers into a short oligonucleotide made of five floxuridine units. Specifically, we studied adding cholesterol, palmitic acid, polyethyleneglycol (PEG 1000), folic acid and triantennary $N$-acetylgalactosamine (GalNAc) as potential enhancers of cellular uptake. As expected, all these molecules increased the internalization efficiency with different degrees depending on the cell line. The conjugates showed antiproliferative activity due to their metabolic activation by nuclease degradation generating floxuridine monophosphate. The cytotoxicity and apoptosis assays showed an increase in the anti-cancer activity of the conjugates related to the floxuridine oligomer, but this effect did not correlate with the internalization results. Palmitic and folic acid conjugates provide the highest antiproliferative activity without having the highest internalization results. On the contrary, cholesterol oligomers that were the best-internalized oligomers had poor antiproliferative activity, even worse than the unmodified floxuridine oligomer. Especially relevant is the effect induced by palmitic and folic acid derivatives generating the most active drugs. These results are of special interest for delivering other therapeutic oligonucleotides.
\end{abstract}

Keywords: 5-fluoro-2'-deoxyuridine; delivery enhancers; cholesterol; palmitic acid; folic acid; GalNAc; conjugation; cancer treatment

\section{Introduction}

Antimetabolites are among the oldest but still the most used drugs for chemotherapy of cancer. These include various compounds such as folic acid analogs, purine and pyrimidine analogs, vinca alkaloids, and many antibiotics and other drugs that disturb nucleic acid metabolism and alter DNA synthesis [1]. 5-fluorouracil (FU) and 5-fluoro-2'deoxyuridine (floxuridine, $\mathrm{FdU}$ ) are some of the antimetabolites commonly used to treat several cancers, including gastrointestinal, breast and other cancer malignancies [2]. FU and FdU effect as antimetabolites is based on the misincorporation of 5-fluoro-2'-deoxyuridine $5^{\prime}$-triphosphate (FdUTP) into DNA in place of TTP or converted to 5-fluorouridine 5' triphosphate (FUTP), which competes with UTP during RNA synthesis. Additionally, 5-fluoro-2'-deoxyuridine in his monophosphate form (FdUMP) inhibits thymidylate synthase [3,4], a key enzyme in the synthesis de novo of DNA biosynthesis. DNA modified with FdU has also been shown to be a potent DNA topoisomerases inhibitor $[5,6]$.

Although FU and FdU are clinically effective drugs, side effects and poor oral absorption have been observed during therapy [7]. Several prodrugs of FdU have been explored to improve its physicochemical and bioavailability properties to reduce toxicity [8]. These include alkyl ester, photoactivated, and amino acid ester FdU prodrugs $[9,10]$. The amino acid ester prodrugs of nucleoside agents have the advantage of being substrates for the 
PEPT1 peptide transporter [11]. Especially relevant studies have been directed to producing effective 5-fluoro-2'-deoxyuridine phosphoramidate compounds, which can release FdUMP intracellularly [12].

Recently, anti-cancer drugs have been conjugated to nanocarriers with efficient selfassembling properties and drug loading. Following the same approach, some authors explored the conjugation of hydrophobic anti-cancer drugs to short peptides [13] or polyethyleneglycol moieties [14].

In parallel, nucleic acid therapeutics mainly based on antisense and siRNA approaches have been employed for treating several diseases [15]. The latest clinical advances in oligonucleotide therapeutics have demonstrated that the conjugation of agents, such as targeting ligands, aptamers, antibodies or peptides, improve their bioavailability and target tissue exposure of these drugs [16]. Extensive works have been reported claiming the importance of these agents $[17,18]$ in the therapeutic oligonucleotide area. Nowadays, there is extensive research in finding small molecules that recognize cell-membrane receptors for active drug targeting [19]. Particularly relevant results have been obtained by the conjugation of siRNA with GalNAc. This carbohydrate moiety is recognized by the asialoglycoprotein receptor, overexpressed in hepatocytes, improving the selectivity and delivery of nucleic acids to these targeted cells [20].

FdU has also been designed as a building block for the DNA synthesis of therapeutic oligonucleotides for cancer treatment [21]. The authors revealed from preclinical studies that polymeric FdU improved the therapeutic window relative to 5-fluorouracil for several cancer types. The cytotoxicity generated by polymeric FdU is due to the degradation to obtain directly FdUMP that can be used to synthesize FdUTP providing stronger activity than conventional fluoropyrimidine drugs in malignancies for which no chemotherapeutic options provide long term survival.

This approach was also exploited in the synthesis of FdU homopolymers conjugated to lipids [22]. The amphiphilic properties of these conjugates produced efficient polymeric micelles that could interact with serum albumin, facilitating their internalization into cancer cells [23]. Recently, taking advantage of the automated and modular synthesis of therapeutic oligonucleotides based on FdU, we described self-assembled rectangle origami and tetrahedron nanoscaffolds as vehicles for tunable FdU payload in colorectal cancer [24]. Pentameric FdU oligonucleotide was also conjugated to the carrier engineered nanoparticle protein carrying a T22 peptide with an affinity for the CXCR4 chemokine receptor. The conjugates showed selective and potent antitumor activity in the metastatic colorectal cancer model compared to pentameric FdU or FdU alone [25].

Following the concept of these examples, we put forward a new set of promising conjugates based on oligomeric FdU. These polymeric drugs with a well-defined structure and payload are linked to small-molecule enhancers or carriers facilitating the incorporation and drug loading to the cells. We selected lipids, such as cholesterol or palmitic acid and more selective or receptor-mediated molecules, such as GalNAc and folic acid. In addition, polyethyleneglycol (PEG) was also investigated as it is reported that their conjugation improves the in vivo pharmacokinetics $[26,27]$ to reach the targeted cells or tissues [28]. Some of these carriers are more specific for certain cell types; however, the general purpose is to determine the impact of different carriers on therapeutic nucleotides' delivery and antiproliferative properties.

\section{Results}

\subsection{Synthesis and Characterization of the $F d U_{5}$ Conjugates}

In this work, we have investigated the effect of several small-molecule internalization enhancers in the antiproliferative and internalization properties of $\mathrm{FdU}_{5}$ oligonucleotide. We have prepared and characterized five $\mathrm{FdU}_{5}$ conjugates (Scheme 1, Table S1) using solid-phase phosphoramidite chemistry. $\mathrm{FdU}_{5}$ linked to cholesterol ( $\left.\mathrm{FdU}_{5}-\mathrm{Col}\right)$, palmitic acid ( $\left.\mathrm{FdU}_{5}-\mathrm{Pal}\right)$ and $\mathrm{GalNAc}\left(\mathrm{FdU}_{5}-\mathrm{GalNAc}\right)$ were synthesized straightforwardly from the corresponding commercial solid supports functionalized with the appropriate deriva- 
tives of the carrier molecules and the phosphoramidite of 5-fluoro-2'-deoxyuridine. For the preparation of the polyethyleneglycol (PEG) FdU conjugate ( $\left.\mathrm{FdU}_{5}-\mathrm{PEG}\right)$, the solid support was prepared following described procedures [29], which can be adapted in principle for any PEG length or shape. In the case of folic conjugated (Folic-FdU ${ }_{5}$ ), we also prepared the solid support containing FdU [25], and after adding the last FdU phosphoramidite, we incorporated an amino group at the $5^{\prime}$-end of the oligonucleotide using the monomethoxytrityl (MMT)-protected 6-aminohexyl phosphoramidite. Then, solid-phase conjugation with folic acid to the amino-oligonucleotide solid support followed by standard ammonia deprotection produced the desired folic acid conjugate (Folic-FdU ${ }_{5}$ ).
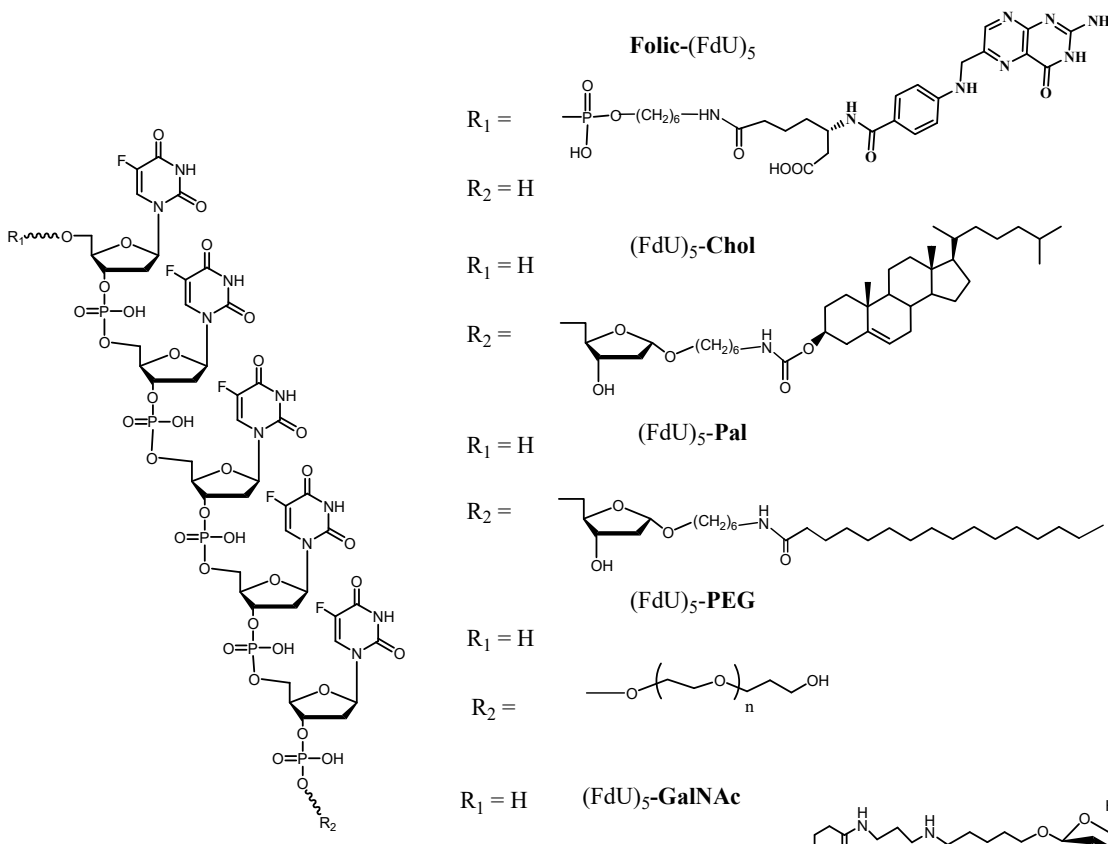

$\mathrm{R}_{2}=\mathrm{H}$

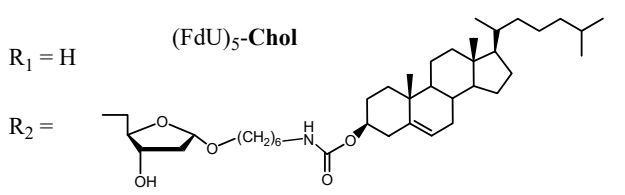

$\mathrm{R}_{1}=\mathrm{H} \quad(\mathrm{FdU})_{5}-\mathrm{Pal}$<smiles>[R]CC1(C)OC(OCCNC(=O)CCCCCCCCCCCC)CC1(C)O</smiles>

$\mathrm{R}_{1}=\mathrm{H}$

$\mathrm{R}_{2}=\mathrm{O}_{\mathrm{n}} \mathrm{O \textrm {OH }}$

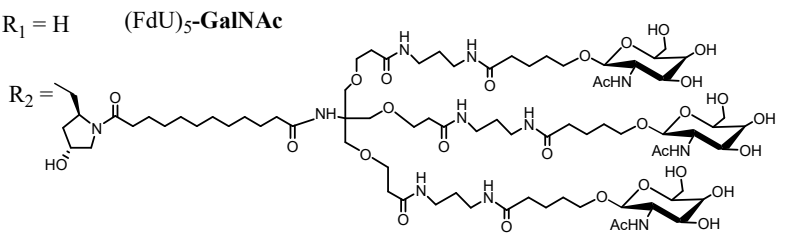

Scheme 1. Chemical structure of the pentameric FdU oligonucleotides with the different carriers synthesized in this work.

\subsection{Enzymatic Degradation of FdU Conjugates}

As mentioned above, in this work, the cytotoxicity generated by oligomeric FdU will come from the degradation of the oligomers to produce FdU and FdUMP. Likely, the potential enhancers of cellular uptake introduced at the $3^{\prime}$ or $5^{\prime}$-ends of the oligonucleotides may affect the degradation by exonucleases without preventing this metabolic activation. To confirm this issue, we have analyzed the behavior of the conjugates in the presence of exonucleases followed by reversed-phase analytical HPLC. We have analyzed the degradation of the conjugates using $5^{\prime}$-phosphodiesterase I (snake venom phosphodiesterase, SVP) and $3^{\prime}$ - phosphodiesterase II (bovine spleen phosphodiesterase, BSP). Results are shown in Table 1 and Figure S1. As anticipated, unmodified $\mathrm{FdU}_{5}$ oligonucleotide was digested in less than one hour using any of both enzymes generating mixtures of FdU and FdU 3 '- or $5^{\prime}$-monophosphates that eluted at the beginning of the chromatogram (Figure S1B,C). The degradation of the $3^{\prime}$ conjugates was slower using the $5^{\prime}$-exonuclease (SVP) because this enzyme starts the degradation at the $3^{\prime}$-end that is blocked by the ligands. However, most of the $3^{\prime}$ conjugates were degraded in $24 \mathrm{~h}$ except for $\mathrm{FdU}_{5}-\mathrm{GalNAc}$ and $\mathrm{FdU}_{5}-\mathrm{Chol}$. On the other hand, the degradation of the $5^{\prime}$ conjugate (folic-FdU ${ }_{5}$ ) by SVP was as fast as the unmodified $\mathrm{FdU}_{5}$ as this oligonucleotide has the $3^{\prime}$-end unmodified. 
Table 1. HPLC analysis of the degradation of $\mathrm{FdU}_{5}$ and $\mathrm{FdU}_{5}$ conjugates by snake venom phosphodiesterase I (SVP) and bovine spleen phosphodiesterase II (BSP).

\begin{tabular}{ccccccc}
\hline \multirow{2}{*}{ Oligonucleotide } & \multicolumn{2}{c}{ Phosphodiesterase I (SVP) } & \multicolumn{3}{c}{ Phosphodiesterase II (BSP) } \\
\cline { 2 - 7 } & $\mathbf{1 . 5} \mathbf{h}$ & $\mathbf{4} \mathbf{h}$ & $\mathbf{2 4} \mathbf{h}$ & $\mathbf{1 . 5} \mathbf{h}$ & $\mathbf{4} \mathbf{~ h}$ & $\mathbf{2 4} \mathbf{~ h}$ \\
\hline$(\mathrm{FdU})_{5}$ & $100 \%$ & - & - & $100 \%$ & - & - \\
$(\mathrm{FdU})_{5}-\mathrm{Chol}$ & $<5 \% *$ & $<5 \% *$ & $<5 \% *$ & $95 \%$ & $100 \%$ & - \\
$(\mathrm{FdU})_{5}-\mathrm{Pal}$ & $5 \%$ & $10 \%$ & $75 \%$ & $90 \%$ & $100 \%$ & - \\
$(\mathrm{FdU})_{5}-\mathrm{GalNac}$ & $4 \%$ & $8 \%$ & $19 \%$ & $8 \%$ & $13 \%$ & $21 \%$ \\
$(\mathrm{FdU})_{5}-\mathrm{PEG}$ & $95 \%$ & $100 \%$ & - & $30 \%$ & $60 \%$ & $100 \%$ \\
Folic-(FdU) & $70 \%$ & $100 \%$ & - & $10 \%$ & $15 \%$ & $30 \%$ \\
\hline
\end{tabular}

* In this case, the peak corresponding to chol-FdU 5 was not observed, but the amount of FdU obtained was estimated by comparison with the amount observed in the degradation of the other conjugates.

The degradation results by 3 '-phosphodiesterase II (BSP) showed in Table 1 demonstrate that most of the conjugates were degraded by BSP except $\mathrm{FdU}_{5}-\mathrm{GalNAc}_{\mathrm{N}}$ and folic$\mathrm{FdU}_{5}$ that were degraded more slowly than the others. This was expected as BSP starts oligonucleotide degradation by the $5^{\prime}$-end that was unmodified in most of the conjugates except for folic-FdU ${ }_{5}$. We cannot explain the retarded degradation of $\mathrm{FdU}_{5}-\mathrm{GalNAc}_{\mathrm{N}}$ except for the fact that the GalNAc ligand may be protected by other proteins present in the spleen preparation.

These results agree with the data described by the group of Gmeiner [21], assigning to floxuridine oligonucleotides the role of acting as prodrugs of FdU. The presence of the ligands at the $3^{\prime}$ or $5^{\prime}$-ends may slow the degradation. Nevertheless, they still can act as the metabolic source of the active FdU drug.

\subsection{Internalization Efficiency of the Different FdU Conjugates}

Once the synthesis was completed, internalization experiments were conducted to evaluate the effect of the ligands on the cellular uptake of the conjugates. For this study, the $\mathrm{FdU}_{5}$ conjugates were labeled with fluorescein phosphoramidite (FAM) at the $5^{\prime}$-end, except for the Folic-FdU ${ }_{5}$ that the fluorophore was assembled at the $3^{\prime}$-end (Table S1). To this end, a new batch of oligonucleotide conjugates was synthesized with the appropriate solid supports and phosphoramidites to introduce the fluorescein. To prevent the unspecific interaction of the $\mathrm{FdU}_{5}$ conjugates with the cellular membrane, the assay was performed by treating the cells with Trypan Blue to quench the extracellular fluorescein and to measure only the intracellular fluorescein signal [30]. Four different cell lines were selected in this study: HeLa (epithelioid cervix carcinoma), HTB-38 and HCC2998 (FU resistant colorectal cancer) and HepG2 (hepatocyte carcinoma).

The $\mathrm{FdU}_{5}$ oligomer without any modification presented different percentages of internalized oligonucleotide (Figure 1 and Figure S2), reaching the maximum in HeLa cells (84\%) and the lowest obtained in HepG2 (10\%). The two colorectal cells HTB38 and HCC2998 presented some differences between them, obtaining labeling of $62 \%$ and $75 \%$ of the cells, respectively. In the case of HeLa cells, the conjugation of $\mathrm{FdU}_{5}$ with all the carriers was found to induce a slight reduction in internalization efficacy, except for cholesterol conjugated with a similar level of internalization as found for $\mathrm{FdU}_{5}$ alone. HepG2 was found to be the most difficult cell line for gymnotic internalization, but the presence of the ligands improved the internalization of $\mathrm{FdU}_{5}$ conjugates. Starting from $10 \%$ of labeled cells for the $\mathrm{FdU}_{5}$ alone to the maximum percentage of labeled cells obtained with folic acid, GalNAc and cholesterol conjugates (38\%, 39\% and 42\%, respectively). Although these internalization values only arrive near $50 \%$ of internalization of the $\mathrm{FdU}_{5}$ conjugates in HepG2, the total increase effect produced by the ligands is the highest value comparing with the other cancer lines. The only carrier unable to increase the internalization of $\mathrm{FdU}_{5}$ in the two colorectal cancer cells was PEG. The conjugation of $\mathrm{FdU}_{5}$ with palmitic or with the folic produced increased the internalization efficiency in both colorectal cancer cell lines of around 15\% in HTB38 and 20\% in HCC2998. However, cholesterol is the carrier 
that produced the best internalization values in both cancer cell lines, similar to what was observed for HeLa cells. The $\mathrm{FdU}_{5}-\mathrm{GalNAc}$ was the only conjugate that presented a considerable difference in the internalization effect between the two colorectal cancer HCC2998 (70\%) and HTB38 (87\%). The internalization increase of GalNAc conjugate in HepG2 cells was expected because of the presence of asialoglycoprotein receptors overexpressed in these cells. However, it is interesting to observe that in the rest of the cancer cell lines, there is also a high internalization of these conjugates. This is probably due to the highly efficient gymnotic uptake of the small $\mathrm{FdU}_{5}$ oligonucleotide in these cell lines.

A

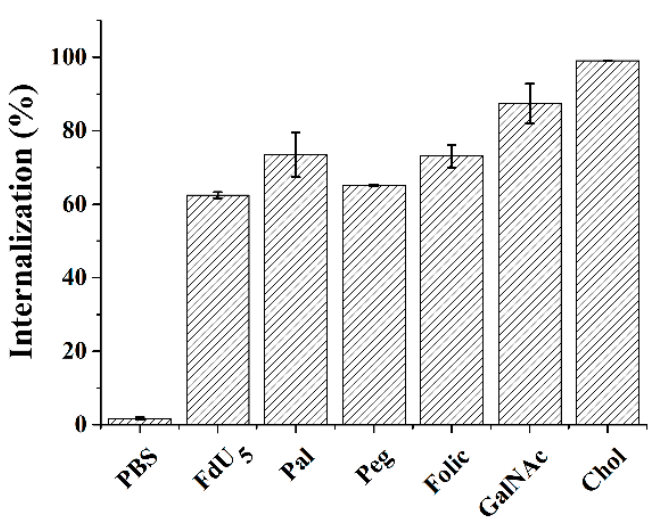

C

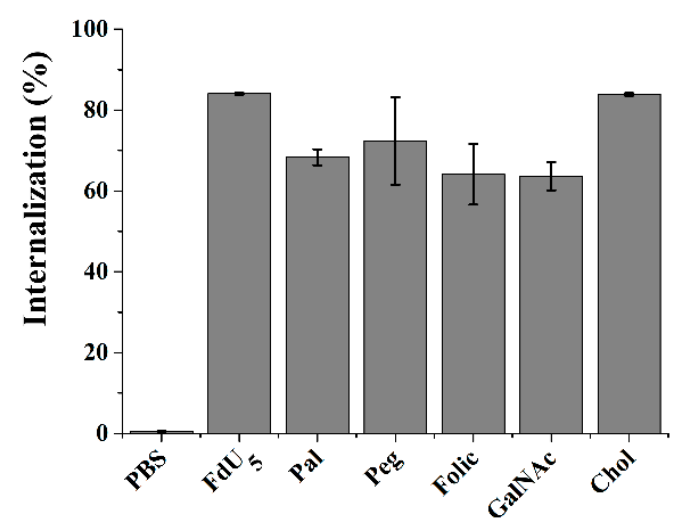

B

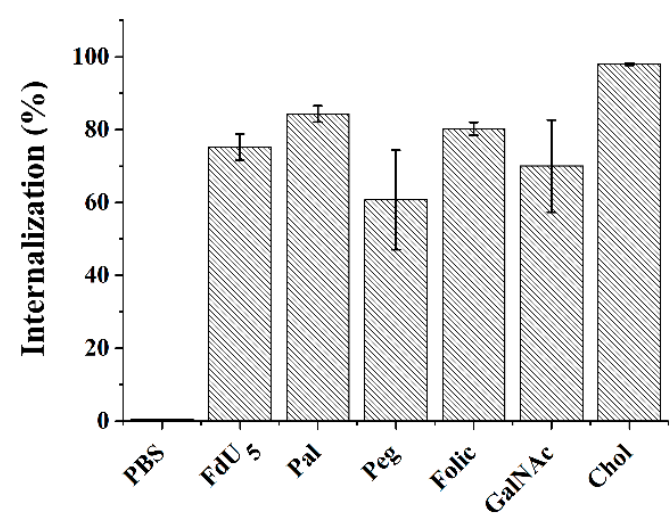

D

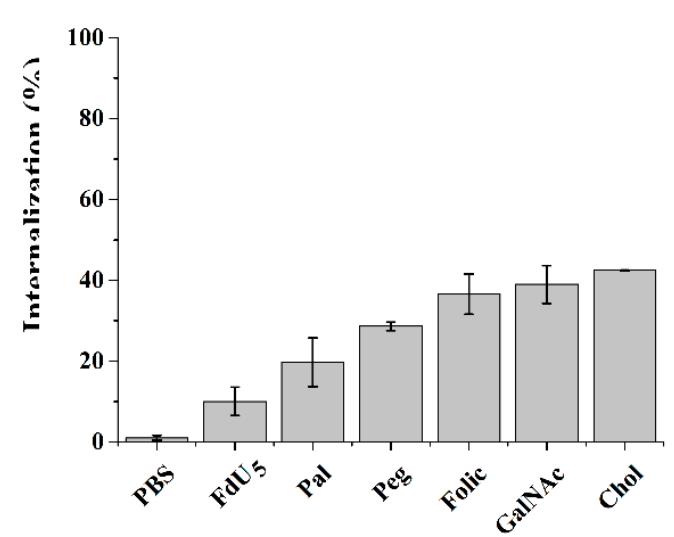

Figure 1. Intracellular uptake of $\mathrm{FdU}_{5}$ and $\mathrm{FdU}_{5}$ conjugate molecules at $5 \mu \mathrm{M}$. The results are presented in bar graphs for the different cell lines (A) HTB38 (B) HCC2998 (C) HeLa, and (D) HepG2 cells. Error bars represent the standard deviation (SD) of two independent experiments.

\subsection{Cytotoxicity Studies of the Different FdU Conjugates}

First, we studied the cytotoxic response obtained for $\mathrm{FdU}_{5}$ oligomer alone as a control in the four cancer cell lines and wild-type fibroblast, at concentrations ranging from $1 \mathrm{nM}$ to $10 \mu \mathrm{M}$ (Table 2 and Figure S3) using the 1-(4,5-dimethylthiazol-2-yl)-3,5-diphenylformazan) (MTT) assay. Comparing the MTT results obtained, it is possible to distinguish a different action of $\mathrm{FdU}_{5}$ oligomer in each type of cell, being HCC2998 the most resistant with an $\mathrm{IC}_{50}$ around $16.9 \mu \mathrm{M}$. The cytotoxicity of the $\mathrm{FdU}_{5}$ oligomer in HTB38 cells is ten-fold higher, with an $\mathrm{IC}_{50}$ of $1.1 \mu \mathrm{M}$, demonstrating the different sensitivity to $\mathrm{FdU}$ derivatives between these two colon cancer cell lines [31,32]. HepG2 are also fairly resistant to $\mathrm{FdU}_{5}$ oligomer with an $\mathrm{IC}_{50}$ of $7.8 \mu \mathrm{M}$. All three cell lines presented a clear resistance to $\mathrm{FdU}_{5}$ cytotoxicity compared to HeLa ( $\left.\mathrm{IC}_{50} 204 \mathrm{nM}\right)$. 
Table 2. $\mathrm{IC}_{50}$ value of $\mathrm{FdU}_{5}$ and $\mathrm{FdU}_{5}$ conjugates.

\begin{tabular}{|c|c|c|c|c|c|}
\hline \multirow{2}{*}{ Oligos } & Fibroblast & HCC2998 & HepG2 & HeLa & HTB38 \\
\hline & $\mathrm{CC}_{50}(\mu \mathrm{M})$ & $\mathrm{IC}_{50}(\mu \mathrm{M})$ & $\mathrm{IC}_{50}(\mu \mathrm{M})$ & $\mathrm{IC}_{50}(\mathrm{nM})$ & $\mathrm{IC}_{50}(\mathrm{nM})$ \\
\hline$(\mathrm{FdU})_{5}$ & $>10,000$ & $\begin{array}{c}16.9 \\
(10.0-33.1)\end{array}$ & $\begin{array}{c}7.8 \\
(5.6-11.3)\end{array}$ & $\begin{array}{c}204 \\
(157-265)\end{array}$ & $\begin{array}{c}1150 \\
(763-1810)\end{array}$ \\
\hline$(\mathrm{FdU})_{5}-\mathrm{Chol}$ & $>10,000$ & $\begin{array}{c}457 \\
(153-2.2 \mathrm{mM})\end{array}$ & $>50$ & $\begin{array}{c}554 \\
(382-823)\end{array}$ & $\begin{array}{c}1650 \\
(1108-2590)\end{array}$ \\
\hline$(\mathrm{FdU})_{5}-\mathrm{Pal}$ & $>100$ & $\begin{array}{c}1.35 \\
(1.05-1.8)\end{array}$ & $\begin{array}{c}9.3 \\
(7.2-12.7)\end{array}$ & $\begin{array}{c}165 \\
(131-206)\end{array}$ & $\begin{array}{c}279 \\
(220-356)\end{array}$ \\
\hline$(\mathrm{FdU})_{5}-\mathrm{GalNac}$ & $>1300$ & $\begin{array}{c}36.5 \\
(19.9-80.7)\end{array}$ & $>50$ & $\begin{array}{c}1140 \\
(874-1490)\end{array}$ & $\begin{array}{c}15,800 \\
(10,800-24,900)\end{array}$ \\
\hline$(\mathrm{FdU})_{5}-\mathrm{PEG}$ & $>180$ & $>50$ & $\begin{array}{c}65.8 \\
(31-201)\end{array}$ & $\begin{array}{c}309 \\
(242-395)\end{array}$ & $\begin{array}{c}1680 \\
(1240-2230)\end{array}$ \\
\hline Folic-(FdU $)_{5}$ & $>10,000$ & $\begin{array}{c}12.5 \\
(9.05-18.4)\end{array}$ & $>50$ & $\begin{array}{c}206 \\
(158-267)\end{array}$ & $\begin{array}{c}870 \\
(652-1170)\end{array}$ \\
\hline
\end{tabular}

The confidence interval is shown between brackets.

Additionally, we have tested the $\mathrm{FdU}_{5}$ derivatives in healthy human fibroblast cells as a model of healthy cells (Table 2, Figures S3 and S8). All the FdU $\mathrm{H}_{5}$ derivatives were found to induce very low cytotoxicity to this human primary cell culture, as shown in Figures S3 and S8 that include the results of the MTT assays performed in the same range of concentrations used for tumor cells $(1 \mathrm{nM}$ to $10 \mu \mathrm{M})$. We estimate a $\mathrm{CC}_{50}$ value that is shown in Table 2. Due to the low cytotoxicity in healthy cells of all the $\mathrm{FdU}_{5}$ conjugates, it was difficult to calculate the selectivity indices $\left(\mathrm{SI}=\mathrm{CC}_{50} / \mathrm{IC}_{50}\right)$. As a broad estimation, the lowest selectivity indices were found for the $\mathrm{FdU}_{5}-\mathrm{PEG}$ conjugate oscillating between 3 and 500 depending on the cell line. For $\mathrm{FdU}_{5}-\mathrm{Pal}$ conjugate, the selectivity indices were between 10 and 1000 and between 13 and 10,000 for FdU ${ }_{5}-$ GalNAc conjugate. The selectivity indices for the rest of the derivatives $\left(\mathrm{FdU}_{5}, \mathrm{FdU}_{5}-\mathrm{Chol}\right.$, folic-FdU $\left.\mathrm{F}_{5}\right)$ were found to be between $10^{3}$ and $10^{5}$.

MTT assays in tumor cells for $\mathrm{FdU}_{5}$ conjugated to the internalization elements are shown in Table 2 and Figure 2 and Figures S4-S7. As observed previously with unconjugated $\mathrm{FdU}_{5}, \mathrm{HCC} 2998$ cells presented a higher resistance for all the $\mathrm{FdU}_{5}$ conjugates. Only the palmitic acid conjugate and, to less extent, the folic acid conjugate seems to potentiate $\mathrm{FdU}$ cytotoxicity having their $\mathrm{IC}_{50}$ value in the low micromolar range $1.4 \mu \mathrm{M}$ and $12.5 \mu \mathrm{M}$, respectively. This behavior is also observed in HTB38, where the palmitic conjugate can reduce fourfold the concentration of $\mathrm{FdU}_{5}$ to reach the $\mathrm{IC}_{50}$ value of $279 \mathrm{nM}$, and the folic acid conjugate also produced a smaller reduction with an $\mathrm{IC}_{50}$ value of $870 \mathrm{nM}$. Surprisingly, $\mathrm{FdU}_{5}-$ GalNAc having the best internalization behavior does not correlate with the cytotoxic effect in the HTB38 cells. The slow degradation of these conjugates by phosphodiesterases may explain this low cytotoxic activity. In the case of HeLa cells, only the palmitic conjugate slightly reduces the concentration necessary to reach the $\mathrm{IC}_{50}$ $(165 \mathrm{nM})$. The rest of the carriers produced similar or less antiproliferative results than the unconjugated FdU, which could indicate that the maximum cytotoxic effect was already achieved. This is consistent with the internalization results obtained for HeLa cells, where the nanocarriers were ineffective in increasing the internalization of the FdU oligomer. 
A

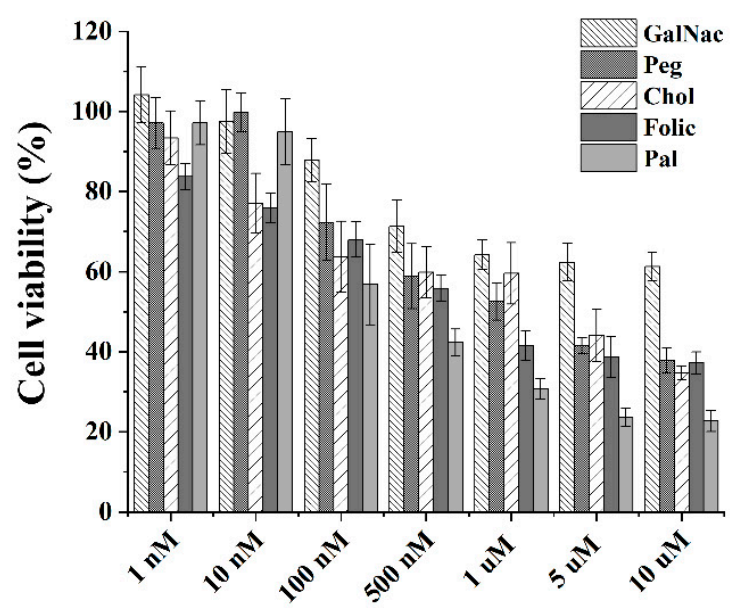

C

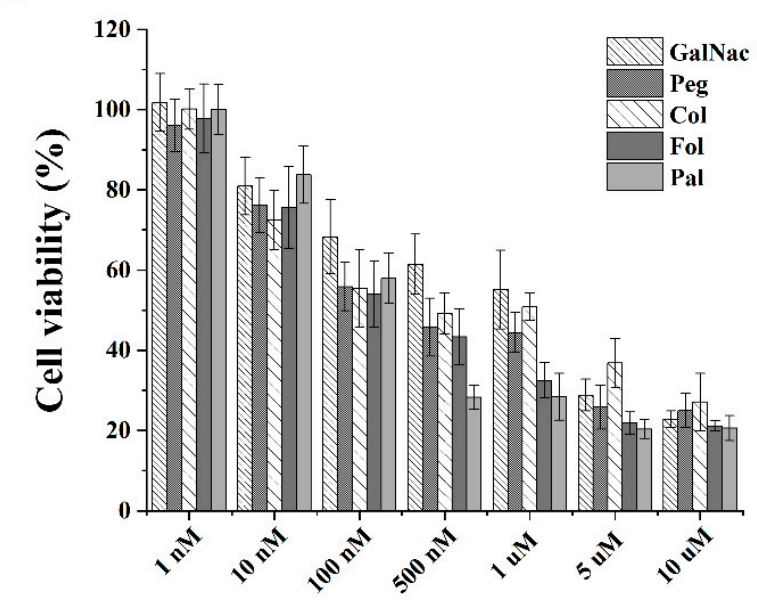

B

HCC2998

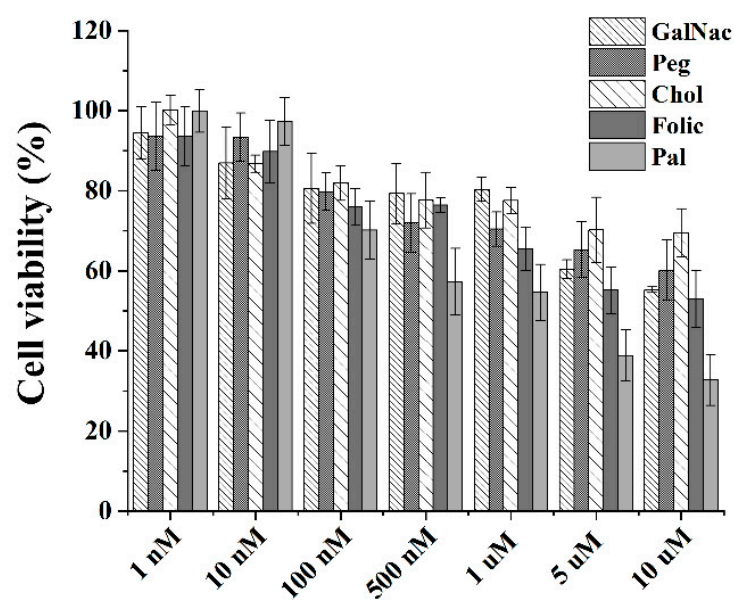

D

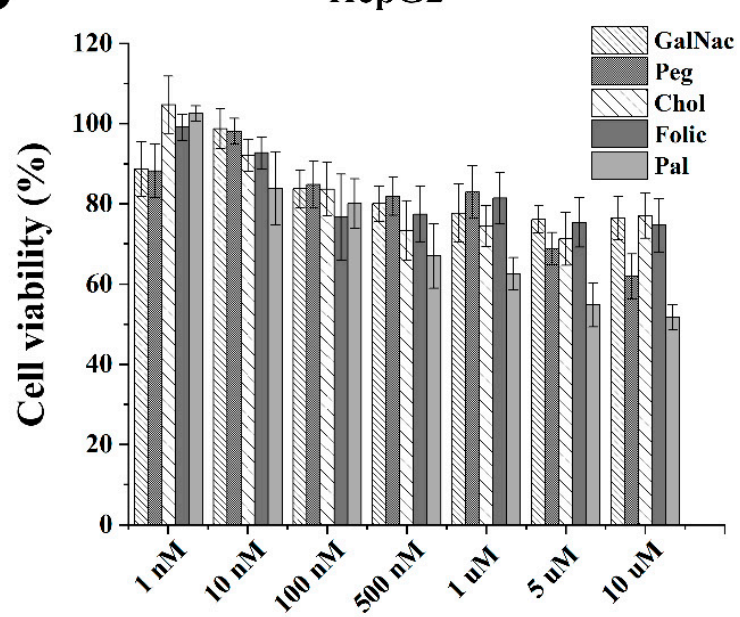

Figure 2. Cytotoxicity activity of the $\mathrm{FdU}_{5}$ conjugates in four cancer cell lines. The MTT assays were performed by treating the cells with various concentrations $(1 \mathrm{nM}$ to $10 \mu \mathrm{M})$ of the oligonucleotide conjugates. Results are presented in bar graphs for the different cell lines (A) HTB38 (B) HCC2998 (C) HeLa, and (D) HepG2 cells. Error bars represent standard deviation (SD) of three independent experiments in triplicate.

Surprisingly, cholesterol and pegylated conjugates were less efficient as cytotoxic agents than unconjugated $\mathrm{FdU}_{5}$. The reducing $\mathrm{FdU}$ antiproliferative effect is probably due to the decreased metabolic generation of the active FdU monophosphate by nuclease degradation, although the slow degradation by phosphodiesterases was only observed for the cholesterol conjugate. Finally, $\mathrm{FdU}_{5}-\mathrm{Pal}$ was ten times more cytotoxic than $\mathrm{FdU}_{5}$, in HCC2998 with a selectivity index of around 100 and four times more toxic in HTB38 cells with a selectivity index of around 400 . These results are especially relevant as these cells are FU-resistant colorectal cancer cells. Finally, in HeLa cells, $\mathrm{FdU}_{5}-\mathrm{Pal}$ and Folic-FdU $\mathrm{U}_{5}$ were the more cytotoxic conjugates together with $\mathrm{FdU}_{5}$. This is especially relevant as Folic-FdU and $\mathrm{FdU}_{5}$ have very low toxicity in healthy fibroblast cell and consequently the selectivity index is higher than $10^{5}$.

To compare the different effects on cell death and to identify the cellular death mechanism involved in reducing cell viability of the $\mathrm{FdU}_{5}$ conjugates, apoptosis assays were conducted. Overall, we found that all the $\mathrm{FdU}_{5}$ conjugates produced a huge increase in late apoptosis, increasing cell death considerably compare with the control in all the cell lines tested (Figure 3). However, we could see different behavior of the FdU nanoconjugates depending on the cell line. In HepG2 cells, no differences in the apoptosis results are 
observed between ligands. This result is similar to the cytotoxicity results obtained in the MTT assay. In HeLa cells, adding cholesterol generated the less effective conjugate being the PEG and the palmitic ligands the most promising ones. As expected, the two colorectal cancer cells showed different responses to each of the $\mathrm{FdU}_{5}$ conjugates being more pronounced in the HTB38. In HTB38, the less effective ligand was the cholesterol conjugate, while in the HCC2998 cell line, PEG conjugate was the less efficient. Clearly, the folic and the palmitic acid ligands are the most promising enhancers to induce apoptosis to cancer cell lines, in agreement with the results obtained in the MTT assay.

A

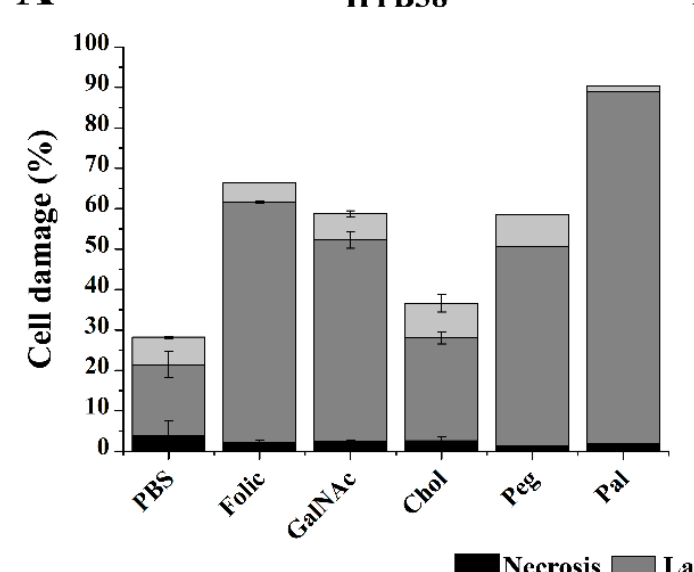

C

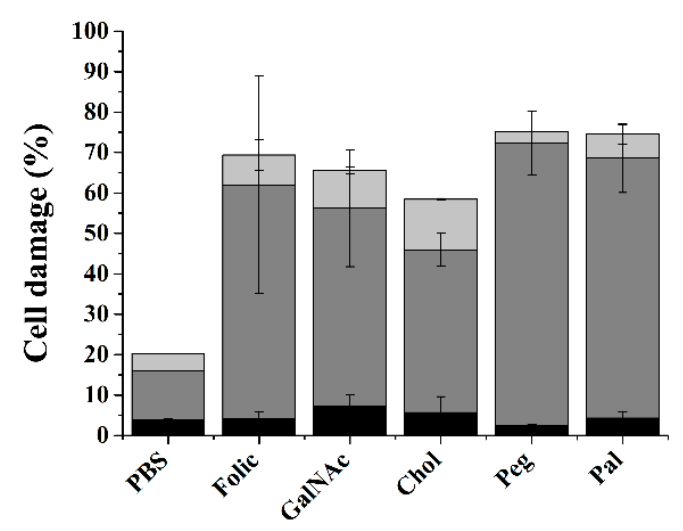

B

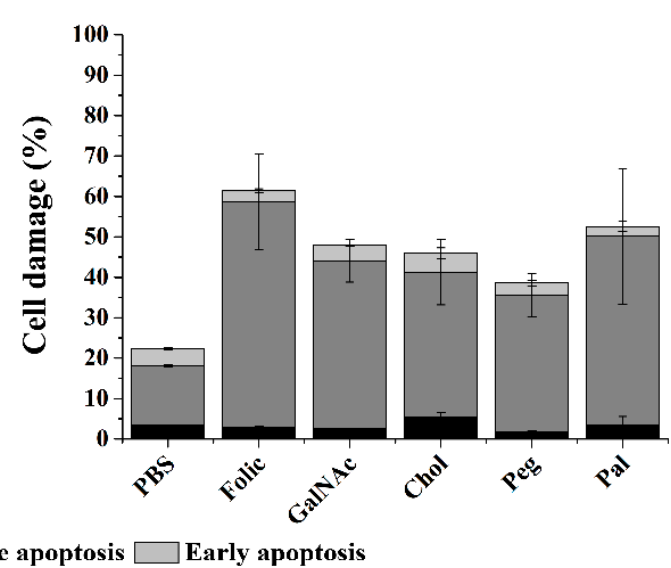

D

HepG2

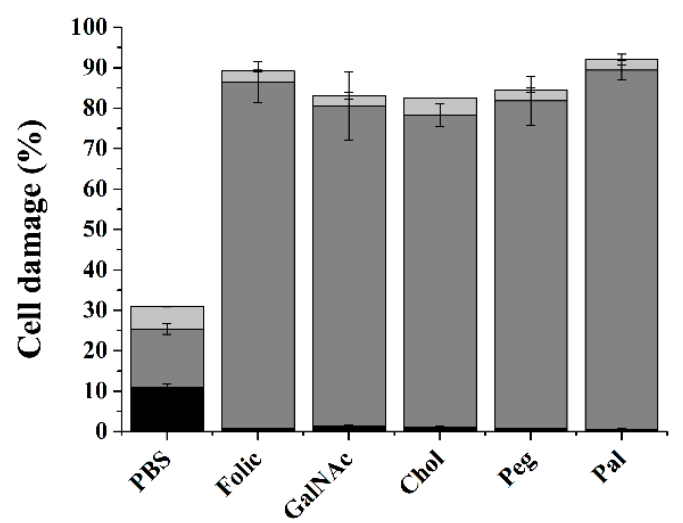

Figure 3. Apoptosis assay comparing the effect produced by the different carriers of FdU $\mathrm{U}_{5}$ in HTB-38 (A), HCC2998 (B), HeLa (C) and HepG2 (D) cells. Error bars represent standard deviation (SD) of two independent experiments.

\section{Discussion}

We have synthesized and evaluated the antiproliferative and internalizing properties of $\mathrm{FdU}_{5}$ conjugates with different ligand molecules demonstrated to facilitate cellular uptake to generate more efficient molecules for cancer therapy. Previous works observed that using pentameric FdU oligonucleotides ligated to a nanoprotein carrier could selectively deliver the FdU drug to metastatic cancer cells improving their pharmacological activity compared to simple $\mathrm{FdU}$ [26]. In this case, the conjugation of $\mathrm{FdU}_{5}$ to a protein with affinity to CXCR4 receptors overexpressed in cancer stem cells delivered the $\mathrm{FdU}_{5}$ oligonucleotide in a very selective and effective way. After this precedent, we were interested in simpler strategies to improve the efficacy of $\mathrm{FdU}_{5}$. In the first approach, we studied the conjugation with lipids moieties. The addition of lipids to oligonucleotides has been used for decades to improve the cellular uptake and biodistribution of oligonucleotides and small drug molecules [33]. Cholesterol was one of the pioneering lipophilic modifications introduced 
in synthetic oligonucleotides, especially in siRNA [34]. Conjugation with cholesterol has demonstrated an important effect on the cellular uptake of therapeutic oligonucleotides, especially in hepatic cells [35]. Palmitic acid has also been introduced in several drugs to enhance delivery to cells. Specifically, it has been introduced at the $5^{\prime}$-end of the sense strand of siRNA, producing an enhancement of the gene-silencing potency due to the nuclease stability and lipophilic character [36].

On the other hand, we considered the attachment of the polymer PEG to the FdU $\mathrm{U}_{5}$ PEGylation has been used for improving the pharmacokinetic properties of therapeutic drugs. Recent studies have demonstrated that this modification improves cellular uptake, gene regulation efficacy and biodistribution of therapeutic nucleic acids [37].

GalNAc conjugation is the more advanced clinical strategy for therapeutic oligonucleotide conjugates (antisense ODN and siRNA). This ligand mediates binding to the specific surface asialoglycoprotein receptor (ASGR) that is overexpressed on the cell surface of hepatocytes and facilitates productive uptake [38]. The introduction of GalNAc to the nucleoside 5-fluoro 2'-deoxyuridine-5'-phosphate via an amide chain linker was described to deliver the drug to hepatic cells [39]. In this case, the cytotoxicity of FdU oligomers is not improved by the GalNAc conjugation as the drug continues to enter cells by passive diffusion, and no evidence for receptor-mediated effects was observed. However, siRNA GalNAc conjugates are taken by the endocytic pathway as active mediated delivery due to the large macromolecule cargo [40]. Most probably, GalNAc modification will be more efficient in directing the delivery of larger oligonucleotides. For short oligonucleotides, such as FdU small oligomers, the best option has been adding palmitic or folic acid ligands with a clear enhancement of the cytotoxicity in FU-resistant colorectal cancer cells (HTB38 and HCC2998).

Among the conjugates studied in this work, $\mathrm{FdU}_{5}-\mathrm{Pal}$ derivative exhibited the highest antiproliferative activity, and, in addition, it is readily prepared from commercially available reagents or by postsynthetic conjugation of amino-oligonucleotides [41,42]. Palmitic acid-antisense oligonucleotide conjugates were first prepared to increase the binding of antisense oligonucleotides with low-density lipoproteins to improve the leishmanicidal efficiency on intracellular amastigotes [43] and to functionalize cell membranes with oligonucleotides [42]. Soon after discovering the RNA interference, it was shown that siRNAs functionalized with palmitic acid at the $5^{\prime}$-end of the sense strand were substrates for dicer and exhibited significant membrane permeability [36]. Very recently, using palmitic acid derivatives of antisense oligonucleotides have been considered excellent alternatives for extrahepatic delivery of therapeutic oligonucleotides [44-46] with enhanced internalization but also enhanced endosomal release [47]. Although all these properties have been found for relatively long oligonucleotides, we could observe some of these excellent properties for short oligonucleotides that must be metabolically activated by nuclease degradation, such as FdU oligomers.

\section{Materials and Methods}

\subsection{Synthesis and Characterization of $F d U_{5}$ Conjugates}

Pentameric FdU conjugates prepared in this study contained a carrier molecule located at the $3^{\prime}$-end except for the folic derivative placed at the $5^{\prime}$-end of the oligonucleotide (Table S1). The conjugates were prepared on a $1 \mu \mathrm{M}$ scale using commercially available solid supports containing cholesterol, palmitic acid (LGC Link Technologies, Lanarkshire, Scotland) and GalNAc (Primetech ALC, Minsk, Belarus). The synthesis of the folic acid conjugates was done at the $5^{\prime}$-end. In this case, we use solid support functionalized with FdU is synthesized using the corresponding DMT-FdU succinate as described [25]. PEG solid support is prepared from the corresponding succinate derivative of PEG 1000 following the described procedure [29]. The procedure is described in the supplementary section. The addition of the FdU phosphoramidite (LGC Link Technologies, Lanarkshire, Scotland) was done following the standard procedures. 
The oligonucleotide carrying folic acid was prepared by solid-phase conjugation of folic acid on pentameric FdU solid support in which an amino group was attached to the $5^{\prime}$ end using the N-MMT-6-aminohexyl phosphoramidite. After adding the amino linker, the monomethoxytrityl (MMT) group was removed using the standard detritylation solution. Then, $1.2 \mathrm{mg}$ ( $2.7 \mu \mathrm{mols})$ of folic acid dissolved in $100 \mu \mathrm{L}$ of anhydrous dimethylformamide (DMF) and activated with PyBOP (benzotriazol-1-yl-oxytripyrrolidinophosphonium hexafluorophosphate), $1.4 \mathrm{mg}(2.7 \mu \mathrm{mols})$ in the presence of $0.94 \mu \mathrm{L}$ diisopropylethylamine (DIEA, $5.4 \mu \mathrm{mols}$ ) for $5 \mathrm{~min}$ and then reacted with $0.2 \mu \mathrm{mols}$ of $5^{\prime}-\mathrm{NH}_{2}$-oligonucleotide solid support for $2 \mathrm{~h}$. Then the solid support was then washed with DMF, acetonitrile $(\mathrm{ACN})$ and dried.

The same oligonucleotide conjugates were prepared for internalization studies as described for the previous sequences using the appropriate fluorescein (FAM) phosphoramidite or the solid support functionalized with fluorescein LGC Link Technologies, Lanarkshire, Scotland) in the opposite end where the carrier molecule was located.

After the assembly of the sequences, the solid supports were treated with aqueous ammonia $(32 \%)$ at $55^{\circ} \mathrm{C}$ for $1 \mathrm{~h}$, filtered, concentrated to dryness and then desalted with a NAP-10 column. For the oligonucleotide with GalNAc derivative, a previous treatment with $0.1 \mathrm{M}$ DBU (1,8-diazabicyclo[5.4.0]undec-7-ene) in ACN for 5 min followed by a $1 \%$ $\mathrm{Et}_{3} \mathrm{~N}$ wash was used to remove the 2-cyanoethyl protecting group. The oligonucleotides were analyzed by HPLC (supplementary material), and the mass expected was confirmed by MALDI-TOF (Table S1).

\subsection{Enzymatic Degradation of FdU $U_{5}$ and the FdU $U_{5}$ Conjugates}

Oligonucleotides were subjected to enzymatic degradation followed by HPLC analysis. Briefly, $0.5-1 \mathrm{OD}_{260}$ unit of the oligonucleotide were dissolved in $92 \mu \mathrm{L}$ of water, $5 \mu \mathrm{L}$ of $1 \mathrm{M}$ aqueous Tris- $\mathrm{HCl}$ solution ( $\mathrm{pH}$ 8.0) and $1 \mu \mathrm{L}$ of $1 \mathrm{M} \mathrm{MgCl}_{2}$ solution. Then $1 \mu \mathrm{L}$ of phosphodiesterase I from Crotalus adamanteus venom (USB) was added and incubated at $37^{\circ} \mathrm{C}$. Then $30 \mu \mathrm{L}$ of the solution was removed heated to $85^{\circ} \mathrm{C}$ for $3 \mathrm{~min}$. For degradation with phosphodiesterase II, the ODN was dissolved in $100 \mathrm{mM}$ sodium acetate $\mathrm{pH} 6.5$ $(100 \mu \mathrm{L})$, and $1 \mu \mathrm{L}$ of phosphodiesterase II from bovine spleens was added. HPLC analysis of the digestion mixture was done using a 15 min linear gradient from 0 to $25 \% \mathrm{~B}$ to analyze the degradation products and then $5 \mathrm{~min}$ at $100 \% \mathrm{~B}$ to elute the non-degraded oligonucleotides.

Conditions of the HPLC analysis of the starting oligonucleotides: a 20 min linear gradient from 0 to $50 \% \mathrm{~B}$ except for $\mathrm{FU}_{5}-\mathrm{Pal}$ and $\mathrm{FU}_{5}-\mathrm{Chol}$ that a 20 min linear gradient from 15 to $85 \%$ with $10 \mathrm{~min}$ at $100 \%$ B was used. Column: Nucleosil C18, $10 \mu \mathrm{m}, 250 \times 4 \mathrm{~mm}$. Buffer A: $5 \%$ acetonitrile $(\mathrm{ACN})$ in $0.1 \mathrm{M}$ triethylammonium acetate (TEAAc) and buffer $\mathrm{B}$ : $70 \%$ ACN 0.1 M TEAAc.

\subsection{Internalization by Flow-Cytometry}

To assess the internalization level of all the modified $\mathrm{FdU}_{5}$ sequences with internalizing elements into these four cancer cells HTB38, HCC2998, HeLa and HepG2, the following procedure was conducted. Cells were seeded in 24-well plates at a density of $8 \times 10^{4}$ cell well $^{-1}$ and incubated for $24 \mathrm{~h}$ before treatment. Next, the oligonucleotides were added directly to the cells, dissolved in a fresh growth medium and incubated. Twenty-four hours after sample addition, cells were washed once with phosphate buffer saline (PBS) and harvested by treatment with trypsin.

\subsection{Cell Proliferation Assay (MTT)}

To determine the effect of the $\mathrm{FdU}_{5}$ sequences conjugated with internalization elements to the cell proliferation, the method of MTT (1-(4,5-dimethylthiazol-2-yl)-3,5diphenylformazan) reduction was carried out. Four cell lines, HTB-38, HCC2998, HepG2 and HeLa, were seeded at $5 \times 10^{4}$ cell well $^{-1}$ in 96-wells plates after ensuring that the seeding density was suitable to guarantee $80 \%$ confluence during experiment completion. 
Twenty-four hours after plating, samples were added in the medium to the cells dissolved in sterile saline buffer and the respective negative controls were included in the experiment. FdU were dissolved in sterile $0.5 \%(v / v)$ DMSO in a culture medium and plated in the same range of concentrations used for the DNA oligonucleotides sequences. After $48 \mathrm{~h}$ of incubation at $37^{\circ} \mathrm{C}$ under $5 \% \mathrm{CO}_{2}$, the MTT reagent was added to a final concentration of $0.5 \mathrm{mg} \mathrm{mL}^{-1}$ to each well and incubated for $2 \mathrm{~h}$. The MTT reduction was read at a single wavelength of $570 \mathrm{~nm}$.

\subsection{Apoptosis by Flow-Cytometry}

The proportion of apoptotic cells resulting from exposition to the DNA oligonucleotides were evaluated by flow cytometry combining fluorescein isothiocyanate (FITC)annexin V and PI. Cells were seeded in duplicate in 24-well plates with a density of $5 \times 10^{4}$ cell well $^{-1}$. Cells were treated with the modified $\mathrm{FdU}_{5}$ sequences and the controls and incubated for $48 \mathrm{~h}$. The attached cells were harvested with trypsin, and floating cells were washed once in cold PBS, pelleted and resuspended in annexin binding buffer plus FITC-annexin V and PI according to the manufacturer's specifications. After staining, samples were analyzed by flow cytometry.

\subsection{Statistical Analysis}

To estimate the inhibitory concentration $\left(\mathrm{IC}_{50}\right)$ of each conjugate and its $95 \%$ confidence intervals, nonlinear regression models were used assuming a symmetrical sigmoidal four-parameters curve [48] for the relationship (GraphPad Prism version 9.0.2 for Windows 64-bit, GraphPad software, San Diego, CA, USA). The response was used in the log form $(\log 10($ dose $))$ rather than the dose itself. After convergence of the models, goodness-offit was checked by looking at the replicates test, the residuals, the covariance matrix of the estimated parameters, the dependence between parameters, and the determination coefficient $\left(R^{2}\right)$.

To compare mean conjugates at the same dose, all pairwise comparisons were performed between conjugates using the unequal variance unpaired $t$-test (Welch's correction). To correct for multiple comparisons, the false discovery rate (FDR) approach was used, setting the maximum desired FDR at 5\% $(Q=0.05)$. The method of FDR used was the Two-stage step-up method of Benjamini, Krieger and Yekutieli $[49,50]$.

To compare means of a conjugate between all doses, pairwise comparisons were performed using the same previous statistical methodology

\section{Conclusions}

In this work, we investigated the biological effects of several enhancers into an oligonucleotide carrying five floxuridine units. First, we observed that all these molecules could increase the internalization efficiency of the oligonucleotide conjugates with different degrees depending on the cell line. Interestingly, the presence of the palmitic acid moiety provided a higher increase in the cytotoxic effects of FdU oligomer with an $\mathrm{IC}_{50}$ value in the low micromolar range $1.4 \mu \mathrm{M}$ in HCC2998, $279 \mathrm{nM}$ in HTB-38 and $165 \mathrm{nM}$ in HeLa. On the contrary, the cholesterol conjugate that was the best-internalized conjugate had poor antiproliferative activity, even worse than the unmodified floxuridine oligomers. As a result, we can conclude that incorporating palmitic and, to a lesser extent, folic acid has a clear benefit in the therapeutic action of the FdU oligomer that can also be extended for delivering other antiproliferative oligonucleotides.

Supplementary Materials: The following are available online at https:/ / www.mdpi.com/article / 10.3390 /ijms22115678/s1, Materials and methods; Preparation of the solid support functionalized with polyethyleneglycol. 
Author Contributions: Conceptualization, A.A.; investigation, A.A., A.C. and C.F.; methodology, A.A., A.C. and C.F.; validation, A.A., A.C., C.F. and M.J.B.; writing-original draft preparation, A.A., A.C. and C.F.; writing-review and editing, A.A., A.C., C.F., M.J.B. and R.E.; supervision, A.A. and C.F.; funding acquisition, R.E. All authors have read and agreed to the published version of the manuscript.

Funding: This research was funded by the Spanish Ministerio de Ciencia e Innovación (CTQ201784415-R) and Generalitat de Catalunya (2017SGR114) and and CIBER BBN (CB06/01/0019). A.C. was funded by a fellowship associated with the CTQ2017-84415-R project (PRE2018-084056).

Institutional Review Board Statement: Not applicable.

Informed Consent Statement: Not applicable.

Data Availability Statement: The data presented in this study are available on request from the corresponding authors.

Acknowledgments: The authors acknowledge the financial support provided by CIBER-BBN, an initiative funded by the VI National R+D+I Plan 2008-2011, IniciativaIngenio 2010, Consolider Program and the Instituto de Salud Carlos III with assistance from the European Regional Development and ICTS NANBIOSIS (Oligonucleotide synthesis platform U29). We are thankful to Diego Arango (Molecular Oncology Group; CIBBIM-Nanomedicine, Vall d'Hebron Institut of Research (VHIR) Barcelona, Spain) for providing the HCC2998 cell line as well as to Fina Cases and Gemma Fabrias (IQAC-CSIC) to provide the primary fibroblast culture.

Conflicts of Interest: The authors declare no conflict of interest.

\section{References}

1. Goodman, L.S.; Gilman, A. The Pharmacological Basis of Therapeutics. Optom. Vis. Sci. 1976, 53, 211. [CrossRef]

2. Cassidy, J.; Saltz, L.; Twelves, C.; Van Cutsem, E.; Hoff, P.; Kang, Y.; Saini, J.P.; Gilberg, F.; Cunningham, D. Efficacy of capecitabine versus 5-fluorouracil in colorectal and gastric cancers: A meta-analysis of individual data from 6171 patients. Ann. Oncol. 2011, 22, 2604-2609. [CrossRef] [PubMed]

3. Grem, J.L. 5-Fluorouracil: Forty-plus and still ticking. A review of its preclinical and clinical development. Investig. New Drugs 2000, 18, 299-313. [CrossRef]

4. Longley, D.B.; Harkin, D.P.; Johnston, P.G. 5-Fluorouracil: Mechanisms of action and clinical strategies. Nat. Rev. Cancer 2003, 3, 330-338. [CrossRef]

5. Jennings-Gee, J.; Pardee, T.S.; Gmeiner, W.H. Replication-dependent irreversible topoisomerase 1 poisoning is responsible for FdUMP[10] anti-leukemic activity. Exp. Hematol. 2013, 41, 180-188.e4. [CrossRef]

6. Gmeiner, W.H. Entrapment of DNA topoisomerase-DNA complexes by nucleotide/nucleoside analogs. Cancer Drug Resist. 2019, 2, 994. [CrossRef]

7. Power, D.G.; Kemeny, N.E. The role of floxuridine in metastatic liver disease. Mol. Cancer Ther. 2009, 8, 1015-1025. [CrossRef]

8. Vivian, D.; Polli, J.E. Synthesis and in vitro evaluation of bile acid prodrugs of floxuridine to target the liver. Int. J. Pharm. 2014, 475, 597-604. [CrossRef] [PubMed]

9. Vig, B.S.; Lorenzi, P.J.; Mittal, S.; Landowski, C.P.; Shin, H.C.; Mosberg, H.I.; Hilfinger, J.M.; Amidon, G.L. Amino acid ester prodrugs of floxuridine: Synthesis and effects of structure, stereochemistry, and site of esterification on the rate of hydrolysis. Pharm. Res. 2003, 20, 1381-1388. [CrossRef] [PubMed]

10. Szymańska-Michalak, A.; Wawrzyniak, D.; Framski, G.; Kujda, M.; Zgoła, P.; Stawinski, J.; Barciszewski, J.; Boryski, J.; Kraszewski, A. New 3'-O-aromatic acyl-5-fluoro-2'-deoxyuridine derivatives as potential anticancer agents. Eur. J. Med. Chem. 2016, 115, 41-52. [CrossRef]

11. Landowski, C.P.; Vig, B.S.; Song, X.; Amidon, G.L. Targeted delivery to PEPT1-overexpressing cells: Acidic, basic, and secondary floxuridine amino acid ester prodrugs. Mol. Cancer Ther. 2005, 4, 659-667. [CrossRef]

12. Jain, H.V.; Kalman, T.I. Synthesis and study of cyclic pronucleotides of 5-fluoro-2'-deoxyuridine. Bioorg. Med. Chem. Lett. 2012, 22, 4497-4501. [CrossRef]

13. Cheetham, A.G.; Zhang, P.; Lin, Y.; Lock, L.L.; Cui, H. Supramolecular nanostructures formed by anticancer drug assembly. J. Am. Chem. Soc. 2013, 135, 2907-2910. [CrossRef]

14. Shen, Y.; Jin, E.; Zhang, B.; Murphy, C.J.; Sui, M.; Zhao, J.; Wang, J.; Tang, J.; Fan, M.; Van Kirk, E. Prodrugs forming high drug loading multifunctional nanocapsules for intracellular cancer drug delivery. J. Am. Chem. Soc. 2010, 132, 4259-4265. [CrossRef] [PubMed]

15. Hu, B.; Zhong, L.; Weng, Y.; Peng, L.; Huang, Y.; Zhao, Y.; Liang, X.-J. Therapeutic siRNA: State of the art. Signal Transduct. Target. Ther. 2020, 5, 101. [CrossRef] [PubMed]

16. Craig, K.; Abrams, M.; Amiji, M. Recent preclinical and clinical advances in oligonucleotide conjugates. Expert Opin. Drug Deliv. 2018, 15, 629-640. [CrossRef] [PubMed] 
17. Benizri, S.; Gissot, A.; Martin, A.; Vialet, B.; Grinstaff, M.W.; Barthélémy, P. Bioconjugated Oligonucleotides: Recent Developments and Therapeutic Applications. Bioconjug. Chem. 2019, 30, 366-383. [CrossRef]

18. Zhao, B.; Tian, Q.; Bagheri, Y.; You, M. Lipid-Oligonucleotide Conjugates for Simple and Efficient Cell Membrane Engineering and Bioanalysis. Curr. Opin. Biomed. Eng. 2020, 13, 76-83. [CrossRef] [PubMed]

19. Kerr, W.G.; Chisholm, J.D. The Next Generation of Immunotherapy for Cancer: Small Molecules Could Make Big Waves. J. Immunol. 2019, 202, 11-19. [CrossRef]

20. Debacker, A.J.; Voutila, J.; Catley, M.; Blakey, D.; Habib, N. Delivery of Oligonucleotides to the Liver with GalNAc: From Research to Registered Therapeutic Drug. Mol. Ther. 2020, 28, 1759-1771. [CrossRef]

21. Gmeiner, W.H.; Debinski, W.; Milligan, C.; Caudell, D.; Pardee, T.S. The applications of the novel polymeric fluoropyrimidine F10 in cancer treatment: Current evidence. Futur. Oncol. 2016, 12, 2009-2020. [CrossRef]

22. Li, N.; Zong, M.-H.; Liu, X.-M.; Ma, D. Regioselective synthesis of 3'-O-caproyl-floxuridine catalyzed by Pseudomonas cepacia lipase. J. Mol. Catal. B Enzym. 2007, 47, 6-12. [CrossRef]

23. Jin, C.; Zhang, H.; Zou, J.; Liu, Y.; Zhang, L.; Li, F.; Wang, R.; Xuan, W.; Ye, M.; Tan, W. Floxuridine Homomeric Oligonucleotides "Hitchhike" with Albumin In Situ for Cancer Chemotherapy. Angew. Chem. Int. Ed. 2018, 57, 8994-8997. [CrossRef]

24. Jorge, A.F.; Aviñó, A.; Pais, A.A.C.C.; Eritja, R.; Fàbrega, C. DNA-based nanoscaffolds as vehicles for 5-fluoro-2'-deoxyuridine oligomers in colorectal cancer therapy. Nanoscale 2018, 10, 7238-7249. [CrossRef] [PubMed]

25. Céspedes, M.V.; Unzueta, U.; Aviñó, A.; Gallardo, A.; Álamo, P.; Sala, R.; Sánchez-Chardi, A.; Casanova, I.; Mangues, M.A.; Lopez-Pousa, A.; et al. Selective depletion of metastatic stem cells as therapy for human colorectal cancer. EMBO Mol. Med. 2018, 10. [CrossRef] [PubMed]

26. Bikhof Torbati, M.; Ebrahimian, M.; Yousefi, M.; Shaabanzadeh, M. GO-PEG as a drug nanocarrier and its antiproliferative effect on human cervical cancer cell line. Artif. Cells Nanomed. Biotechnol. 2017, 45, 568-573. [CrossRef]

27. Veronese, F.M.; Pasut, G. PEGylation, successful approach to drug delivery. Drug Discov. Today 2005, 10, 1451-1458. [CrossRef]

28. Banerjee, S.S.; Aher, N.; Patil, R.; Khandare, J. Poly(ethylene glycol)-Prodrug Conjugates: Concept, Design, and Applications. J. Drug Deliv. 2012. [CrossRef]

29. Jäschke, A.; Fürste, J.P.; Nordhoff, E.; Hillenkamp, F.; Cech, D.; Erdmann, V.A. Synthesis and properties of oligodeoxyribonucleotidepolyethylene glycol conjugates. Nucleic Acids Res. 1994, 22, 4810-4817. [CrossRef] [PubMed]

30. Van Bracht, E.; Versteegden, L.R.M.; Stolle, S.; Verdurmen, W.P.R.; Woestenenk, R.; Raavé, R.; Hafmans, T.; Oosterwijk, E.; Brock, R.; van Kuppevelt, T.H.; et al. Enhanced Cellular Uptake of Albumin-Based Lyophilisomes when Functionalized with Cell-Penetrating Peptide TAT in HeLa Cells. PLoS ONE 2014, 9, e110813. [CrossRef]

31. Mariadason, J.M.; Arango, D.; Shi, Q.; Wilson, A.J.; Corner, G.A.; Nicholas, C.; Aranes, M.J.; Lesser, M.; Schwartz, E.L.; Augenlicht, L.H. Gene expression profiling-based prediction of response of colon carcinoma cells to 5-fluorouracil and camptothecin. Cancer Res. 2003, 63, 8791-8812.

32. Bracht, K.; Nicholls, A.M.; Liu, Y.; Bodmer, W.F. 5-Fluorouracil response in a large panel of colorectal cancer cell lines is associated with mismatch repair deficiency. Br. J. Cancer 2010, 103, 340-346. [CrossRef]

33. Ugarte-Uribe, B.; Grijalvo, S.; Pertíñez, S.N.; Busto, J.V.; Martín, C.; Alagia, A.; Goñi, F.M.; Eritja, R.; Alkorta, I. Lipid-modified oligonucleotide conjugates: Insights into gene silencing, interaction with model membranes and cellular uptake mechanisms. Bioorg. Med. Chem. 2017, 25, 175-186. [CrossRef] [PubMed]

34. Wolfrum, C.; Shi, S.; Jayaprakash, K.N.; Jayaraman, M.; Wang, G.; Pandey, R.K.; Rajeev, K.G.; Nakayama, T.; Charrise, K.; Ndungo, E.M.; et al. Mechanisms and optimization of in vivo delivery of lipophilic siRNAs. Nat. Biotechnol. 2007, 25, 1149-1157. [CrossRef] [PubMed]

35. Cheng, K.; Ye, Z.; Guntaka, R.V.; Mahato, R.I. Enhanced Hepatic Uptake and Bioactivity of Type $\alpha 1$ (I) Collagen Gene PromoterSpecific Triplex-Forming Oligonucleotides after Conjugation with Cholesterol. J. Pharmacol. Exp. Ther. 2006, 317, 797-805. [CrossRef] [PubMed]

36. Kubo, T.; Yanagihara, K.; Takei, Y.; Mihara, K.; Morita, Y.; Seyama, T. Palmitic Acid-Conjugated 21-Nucleotide siRNA Enhances Gene-Silencing Activity. Mol. Pharm. 2011, 8, 2193-2203. [CrossRef] [PubMed]

37. Lu, X.; Zhang, K. PEGylation of therapeutic oligonucletides: From linear to highly branched PEG architectures. Nano Res. 2018, 11, 5519-5534. [CrossRef]

38. Huang, Y. Preclinical and Clinical Advances of GalNAc-Decorated Nucleic Acid Therapeutics. Mol. Ther. Nucleic Acids 2017, 6, 116-132. [CrossRef]

39. Rico, L.; Østergaard, M.E.; Bell, M.; Seth, P.P.; Hanessian, S. Studies directed toward the asialoglycoprotein receptor mediated delivery of 5-fluoro-2'-deoxyuridine for hepatocellular carcinoma. Bioorg. Med. Chem. Lett. 2018, 28, 2652-2654. [CrossRef]

40. Springer, A.D.; Dowdy, S.F. GalNAc-siRNA Conjugates: Leading the Way for Delivery of RNAi Therapeutics. Nucleic Acid Ther. 2018, 28, 109-118. [CrossRef]

41. Martín-Nieves, V.; Fàbrega, C.; Guasch, M.; Fernández, S.; Sanghvi, Y.S.; Ferrero, M.; Eritja, R. Oligonucleotides Containing 1-Aminomethyl or 1-Mercaptomethyl-2-deoxy-D-ribofuranoses: Synthesis, Purification, Characterization, and Conjugation with Fluorophores and Lipids. Bioconjug. Chem. 2021, 32, 350-366. [CrossRef]

42. Borisenko, G.G.; Zaitseva, M.A.; Chuvilin, A.N.; Pozmogova, G.E. DNA modification of live cell surface. Nucleic Acids Res. 2009, 37, e28. [CrossRef] 
43. Ramazeilles, C.; Mishra, R.K.; Moreau, S.; Pascolo, E.; Toulme, J.J. Antisense phosphorothioate oligonucleotides: Selective killing of the intracellular parasite Leishmania amazonensis. Proc. Natl. Acad. Sci. USA 1994, 91, 7859-7863. [CrossRef] [PubMed]

44. Prakash, T.P.; Mullick, A.E.; Lee, R.G.; Yu, J.; Yeh, S.T.; Low, A.; Chappell, A.E.; Østergaard, M.E.; Murray, S.; Gaus, H.J.; et al. Fatty acid conjugation enhances potency of antisense oligonucleotides in muscle. Nucleic Acids Res. 2019, 47, 6029-6044. [CrossRef] [PubMed]

45. Østergaard, M.E.; Jackson, M.; Low, A.; Chappell, A.E.; Lee, R.G.; Peralta, R.Q.; Yu, J.; Kinberger, G.A.; Dan, A.; Carty, R.; et al. Conjugation of hydrophobic moieties enhances potency of antisense oligonucleotides in the muscle of rodents and non-human primates. Nucleic Acids Res. 2019, 47, 6045-6058. [CrossRef] [PubMed]

46. Chappell, A.E.; Gaus, H.J.; Berdeja, A.; Gupta, R.; Jo, M.; Prakash, T.P.; Oestergaard, M.; Swayze, E.E.; Seth, P.P. Mechanisms of palmitic acid-conjugated antisense oligonucleotide distribution in mice. Nucleic Acids Res. 2020, 48, 4382-4395. [CrossRef] [PubMed]

47. Wang, S.; Allen, N.; Prakash, T.P.; Liang, X.; Crooke, S.T. Lipid Conjugates Enhance Endosomal Release of Antisense Oligonucleotides Into Cells. Nucleic Acid Ther. 2019, 29, 245-255. [CrossRef] [PubMed]

48. Ratkowsky, D.A.; Giles, D.E.A. Handbook of Nonlinear Regression Models; M. Dekker: New York, NY, USA, 1990 ; ISBN 0824781899.

49. Benjamini, Y.; Krieger, A.M.; Yekutieli, D. Adaptive linear step-up procedures that control the false discovery rate. Biometrika 2006, 93, 491-507. [CrossRef]

50. Glickman, M.E.; Rao, S.R.; Schultz, M.R. False discovery rate control is a recommended alternative to Bonferroni-type adjustments in health studies. J. Clin. Epidemiol. 2014, 67, 850-857. [CrossRef] 